This is a pre-copyedited, author-produced PDF of an article accepted for publication in Journal of Neonatal Nursing following peer review. Subject to 12 months embargo period, embargo end date: 7 September 2017.

The version of record [Journal of Neonatal Nursing (December 2016) Vol 22 (6): 297-308. First published online September 7, 2016] is available online at doi: http://dx.doi.org/10.1016/i/.jnn.2016.08.005

(C) 2016. This manuscript version is made available under the CC-BY-NC-ND 4.0 license http://creativecommons.org/licenses/by-nc-nd/4.0/. 


\title{
LEARNING FROM NARRATIVE TO UNDERSTAND THE PERSON-CENTRED EXPERIENCE IN NEONATAL NURSING: A LITERATURE REVIEW.
}

\begin{abstract}
Introduction: Within healthcare, narrative can be a compelling way to teach professionals about patient experience and foster a more humanistic, person-centred understanding of care. The neonatal nursing field is a speciality with specific learning needs relating to the neonate within the family centred context that requires a person-centred understanding of the parent experience. Little has been investigated or written about how narrative can inform teaching and learning about person-centred care in this area.
\end{abstract}

Objectives: To identify key literature that explores the narratives of parents or nurses with a view to evaluating their value for enhancing learning about person-centred nursing care in the neonatal field.

Design: A literature review was undertaken focusing on qualitative research exploring parents or nurse's experience through narrative and learning from that experience within neonatal care.

Data sources: The databases identified as most suitable to their relevance to nursing were accessed through EBSCO host and a local University consolidated library search system. Review methods: Primary, Boolean and advanced searches on key terms were performed. Purposive sampling of the literature was used and inclusion and exclusion criteria were applied. A final selection of nine studies was put forward for review.

Findings: Analysis of the selected literature found that attention to the narratives of both parents and nurses in the neonatal field reveal important insights into the lived experiences of being part of this often challenging field. This offers opportunities to open up professional practice for discussion providing an effective vehicle for students and nurses to learn about 
and discuss these experiences in the neonatal field. This in turn can offer a more compassionate, person-centred approach to the care of neonates, parents and staff in this area. Conclusion: There is a place for the integration of narrative in the form of storytelling into teaching and learning strategies that capture the experience of those within the neonatal field that can be used to support teaching and learning about person-centred neonatal nursing care.

\section{KEY WORDS}

Narrative

Neonatal Nursing

Understanding experience

Person-centred learning

\section{INTRODUCTION}

The central focus of this literature review and subsequent analysis is learning about the human experience from narrative within nursing practice, to apply to the field of neonatal care. More specifically, its asks what narrative reveals about the experiences of both patients and nurses in order for others to learn from and understand them, specifically in relation to a person-centred approach to neonatal nursing care. Person centred care, defined as that involving compassion, empathy and respect, are the essential foundations of nursing care. Such a humanistic approach places the person as the central focal point of attention. In other words, there is a link between narrative and the exploration of stories to enable a deeper understanding of this individual, human experience (Andrews et al, 2013) which in turn is said to lead to more compassionate, empathic and person-centred nursing care (Charon, 2006). 
Narrative is defined as a spoken or written account of events or experiences. Indeed, this definition can also include 'story' which is defined as a series of connected events that takes the reader with them and comprises a start, a main body and usually a conclusion or end point, whether true or fictitious (Wright et al, 2014) . By this, a narrative can be a story but not necessarily. However, a story is a type of narrative. For the purposes of this review, the terms will be used interchangeably. To add, within neonatal care, patient' refers to that of the parents' experience since we cannot explore the narratives of the neonate themselves.

The majority of literature in the area of narrative healthcare is placed within the adult field; less so in children's and neonatal care which presents an evidence gap. The current review however aims to harness key messages from a selection of key literature and focuses on how we can use the narratives of health professionals and patients to explain and enhance a person-centred understanding within the neonatal field specifically. This review of the literature therefore identifies and analyses key papers relevant to the question; what can be learnt about the patient experience from narrative to enhance understanding of a personcentred approach to neonatal nursing care?

\section{BACKGROUND}

The theoretical background to the use of narrative can be explained by Bruner's (1991) 'narrative construction of reality' who believes that we organise our experience and memory of what happens to us mainly in the form of narratives - i.e. stories. Narratives are an individual version of reality and are at the heart of all 'meaning-making'. Here, there lies a place for narrative within a constructivist theoretical framework whereby individuals learn and experience the world through narrative and 'storied' lives that are constructed within an individual context. The psychologist, Polkinghorne (1988) also focuses on the concept of meaning and defines narrative as a story that relates a series of events by which we learn about the world. He refers to this as 'narrative knowing' and views stories as being a 
fundamental tool to explore human science, both theorist believing that narratives have a special and powerful explanatory potential.

In the context of healthcare, a story is defined therefore as a unique human experience through which patients find meaning in their past or present experience, express emotions and connect and relate to other people (Christiansen, 2011; Hardy and Haigh, 2011) during their healthcare encounter. Stories are regarded as a powerful way to show professionals human experience and encourage sensitive, individualised, compassionate care within the remit of narrative healthcare (Charon, 2006; Hardy, 2007; Stacey and Hardy, 2011).

Das Gupta (2007) believes that illness narratives from children and their families hold 'unique insights' in how to 'engage in an ethical, empathetic and self-reflective practice' (pg. 1384). He also explains in relation to what he terms 'between illness and stories', how health professionals should be able, in a humanistic caring perspective, to construct stories about patients in order to understand them better; this should apply whether they are non-verbal neonates to the adolescent later in life.

A common and general conclusion drawn from the literature is that narrative in the form of stories have common benefits for the value to learning about the patient. However, Lorem (2008) warns of an over-reliance on narrative in healthcare in that, while narratives are important as a source of knowledge about patient experiences and their life world, there may also be a potential risk, reducing thinking about patients as if they were texts. This is where a person-centred approach to understanding health and education is essential. As we listen or read the stories, we must not forget the person at the centre of the inquiry; in the current context, this is the neonate and family. 


\begin{abstract}
$\underline{\text { AIM }}$
The approach to literature search began with identifying the underlying aim of the review as a whole, arising from the question stated above; namely, to reach a greater understanding of the value of narrative in the field of neonatal nursing so that nurses can learn to understand individual experience and apply this to enhancing person-centred care of the neonate and family.
\end{abstract}

\title{
REVIEW METHOD AND SEARCH STRATEGY
}

Search terms were selected and then combined; for example, 'narrative', 'story' OR 'storytelling'; AND 'nurse education'. To refine the search further it was necessary to apply limits and therefore research papers were selected that had been published within the previous 10 years. In addition, the review is centred on the use of narrative and stories in nursing specifically within a teaching and learning context; literature was therefore excluded within other disciplines applicable to health. It was also necessary to limit the field of nursing to the neonatal care specifically. The final stage of the literature selection for review was undertaken by extracting those papers that focused on exploring experience and learning from that experience within the neonatal nursing field; i.e.; those studies that were found to contribute to teaching and learning about humanistic elements of nursing care. A summary of the search strategy including search terms, and the inclusion and exclusion criteria applied can be seen in Table 1. 


\section{FINDINGS}

The paper will now discuss the findings and relevant aspects in relation to the selected studies. Within neonatal care, it was found that work that has investigated both parents and nurses' experiences has used phenomenological, hermeneutic approaches to explore and interpret narratives. Therefore, the review will focus on these two common themes; namely, learning from parents' narratives and learning from nurses' narratives in neonatal care. The reader should refer to Table 2 for a summary and critique of each study along with their contribution to a person-centred understanding.

\section{Learning from parent narratives}

Firstly, a study by Wigert et al (2006) aimed to describe mothers' experiences when their full-term neonate was cared for in a neonatal unit during the postnatal period. Ten mothers were interviewed six months to six years after their experience in a neonatal unit. The essence of the experience was understood as two alternating concepts; exclusion and participation. A feeling of exclusion dominates when a new mother felt lack of interaction and a sense of not belonging to either the maternity care unit or the neonatal unit leading to negative maternal feelings. Conversely, when a feeling of participation dominated, a continuous dialogue existed and the mother was cared for as a unique person with specific needs supporting her maternal feelings positively. While there was a varied and wide time periods in which interviews occurred, the implication of these results for nurses is that they learn the importance of decreasing mothers' experience of exclusion and to increase their feeling of participation by promoting a 'dialogue', a term very congruent with a focus on narrative. 
Fegran and Helseth (2009) also used an exploratory design to explore both parents' and nurses' experiences of the parent-nurse relationship but focused on when a preterm neonate is hospitalized. This study used both participant observation and in-depth interviews with six mothers, six fathers and six nurses in a Norwegian 13-bed neonatal unit. It was found that that neonatal unit context is a technological environment where human interaction is a crucial issue, promoted by participation similar to the above study by Wigert. However, interestingly, closeness increased the emotional involvement and blurred the boundaries between the parent and professional. Therefore, the commitment of being close combined with the emotional involvement, was found to be a burden to both parents and nurses. This study shows how narratives can reveal deep rooted, humanistic elements of one's experience, against the back drop of the high tech, neonatal environment so emphasising a person centred focus and the need for this to be recognised.

With a similar aim, Dellenmark-blom and Wigert (2014) undertook a descriptive study of parents' experiences but in relation to neonatal home care following initial care in the neonatal unit. A larger sample than the above two studies was selected for interview and the main finding was that parents experience neonatal home care as an inner emotional journey, from having a baby to being a parent. This finding derives from many themes: the parents' experience of leaving the hospital environment, establishing independent parenthood, maturing as a parent and processing experiences during the period of neonatal care. This concept of 'journey' is consistent with that of 'story'- i.e. a series of transitions over a course of time where one narrates their experiences through this progression.

Russell et al (2014) also paper explored parents' views and experiences of the care for their premature neonates by interviews with mothers and fathers. Although parents' evaluation of 
care in the NICU was not the aim of these interviews, all parents spoke spontaneously and at length on this topic. Generally, parents were satisfied with the care on the neonatal unit in relation to their involvement and looking after their own neonate, easy access to them and the challenges of expressing breast milk. They were also satisfied with staff competence and efficiency, communication, experience, confidence, information and explanations. The final area of satisfaction related to the interpersonal relationships with staff including sensitive and emotional support, reassurance, encouragement and the importance of being made to feel like an individual. Provision of information, support for parents and increasing their involvement in the care of their neonate were highlighted by parents as important in their experience of personal-related care, all common themes also identified in the previous studies above.

Finally, Wigert et al (2014) aimed to describe parents' experiences of communication with neonatal staff. Families were interviewed and it was found that parents experienced communication with the staff as essential to their management of their situation. Attentive communication gives the parents relief in stressful circumstances. In contrast, lack of communication contributes to feelings of loneliness, abandonment and unwanted responsibility, which added to the burden of an already difficult situation. 'Burden' is a term highlighted in the previous study by Fegran and Helseth, again underlining the emotional tensions revealed by parents' narratives. This study stands out as it puts forward what can be learnt by health professionals; mainly that, staff should be reminded of their unique position to help parents handle their emotional difficulties. There should be opportunities for good communication between parents and staff through training, staffing and the physical health care environment. 


\section{Learning from the narratives of nurses}

Narrative clearly has been shown to have power in identifying complex emotions and experience in parents relating to person centred elements of care. Studies exploring the narratives of staff working in neonatal care has also highlighted interesting aspects of their experience and there is also much to learn from the experiences and narratives of nurses.

A study by Lindsay et al (2012) explored the experiences of neonatal nurses with end-of-life care of neonates and their families, a challenging topic that requires the utmost sensitivity, empathic and compassionate care, all essential elements of a person-centred approach to care. Nurses were met twice in small groups and once on the telephone to share their stories that they had written themselves about specific cases. Common elements of the nurses' stories included forming relationship patterns with parents, and knowledge construction about death and suffering that assisted the nurse to deal with the tensions experienced from what the investigators termed spatial and temporal proximity. The findings revealed what the authors termed 'essential engagement' with regards to the relationship between the baby and the nurse. This became of primary importance in a 'call-to-presence' role; i.e. the nurse was called to understand the baby's story, to pay attention to the behaviour and responses of the baby and family to the situation and to the care. The nature of end-of-life care is undoubtedly a difficult and challenging one recognising the significant stress placed upon the parents and how demanding it can be for nurses to deal with sensitive issues. Again, as with Fegran and Helseth's study cited earlier, the issue of 'relationship' was also identified by Lindsay et al. It appears that while relationships between nurses and parents are important, this does give rise to potential pressures. A key point here is how narrative has the power to draw out such 
complexities relating to person centred elements of care, rather than the technological aspects of care and the clinical environment.

Brodsky et al (2013) also broached this sensitive issue and explored the health professional's perspective of difficult conversations in neonatal critical care. A larger study, they analysed seventy-four narratives from health professionals in neonatal care asking them to describe a difficult conversation and to consider the extent to which it was challenging or satisfying or both. It was found that such conversations are certainly more challenging and difficult than satisfying. For both this and the previous study by Lindsay et al (2012), the authors' conclusions lead to proposals for design of communication and relationship focused educational strategies to assist health professionals in this area. It also identifies the importance of teaching and learning strategies to facilitate person-centred education involving enhancement of communication and human understanding to apply to the care environment.

Korhonen and Kangasniemi (2014) concur with this suggestion for future practice development and discuss how important it is to study the caring relationship between the primary nurse and the parents of a hospitalised baby/child. They believe that the caring relationship is the core of nursing and needs to be considered in research, supported in practice and indeed, by tailored education. These authors also undertook a study with the aim to describe nurses' experiences of ending the primary nursing relationship with the parents in neonatal intensive care. Nursing in the neonatal intensive care unit enables a long-lasting caring relationship with the parents but terminating this kind of relationship is not often discussed. A qualitative, narrative design was used with in-depth interviews, analysed with Polkinghorne's model of narrative analysis and emplotment principle: i.e. the plot makes the 
narrative understandable and clarifies connections between events. The resulting narratives described the relationship between the primary nurse and the parents as a plot through caring for the baby leading to when this relationship ended. The common shared theme throughout was how nurses regulated the relationship between closeness / connection and distance.

Finally, Green at al (2014) used set out to explore how neonatal nurses draw meaning from their experiences with extremely preterm neonates, focusing on the nature of the patient themselves. The focus of the above studies were relationships with parents in the main so this study offers another perspective. Using interview data and the identification of thematic statements from semi structured interviews with nurses, they found that they revealed many challenges in caring for such small, vulnerable babies. These included the fact that the babies appear like foetuses rather than full term babies. They also concluded that these difficulties were dealt with by using strategies that minimised the appearance of a very premature baby and maximised that of a full term, newborn baby. They also often used depersonalisation and detachment to prevent themselves becoming too attached until they felt able to handle the situation or until the baby matured. This study stands out as it focuses on the actual neonate themselves and the experiences associated with the care of such unique, immature patients.

\section{DISCUSSION}

The discussion will include the significance of the above literature review and analysis to both neonatal practice and implications for teaching and learning in this area.

Application to person-centred care: In relation to a summary of the review findings, an overarching key theme arising is how narratives can reveal insights into experience of those 
who are within a specific area, be they parents or nurses. As can be seen in Table 2, studies that have explored parents experience centre around many important concepts that have a profound impact on how they feel and function as a parent; these included feeling excluded, the need to participate in their baby's care and the importance of effective communication, positive human interaction and dialogue between themselves and staff. Parents also reflected on the significance of their 'journey' through neonatal care and how much it meant to them. Analysing nurses' experiences can be an influential strategy for opening up professional practice for discussion providing an effective vehicle for students to critically challenge areas of practice.

Making sense of, and learning from this experience in this specific field of health and what can nurses learn about their practice in the care of neonates and their families is key to more effective person-centred neonatal care. Neonatal care is a distinct area of children's nursing and one that offers the learner a wide variety of diverse skills and knowledge areas including one very important topic, that of preterm birth and it many facets. The implications of preterm birth and the subsequent neonatal care along with the often-protracted 'journey' through the neonatal unit, is one that offers huge opportunities for learning. Traditionally, education has focused and still does, on technological advances and clinical skills necessary to care for these very vulnerable patients and their families. However, less attention has always been centred on person-centred care - i.e. as a different area to technological care. Person centred care, defined earlier as that involving compassion, dignity and respect, all essential to optimum nursing care \& in specific relation to neonatal care, all vital in the care and support of parents who undergo huge emotional distress and turmoil. Therefore, there is much to be learnt from analysis of the literature that focuses on humanistic elements of care through narrative. 
Stories also enable a qualitative approach to healthcare education as different to the traditional, quantitative and objective, audit based data that is collected on a vast range of care practices within healthcare. Far better to improve the patient experience is to use the former approach that focuses on humans rather than numbers. Lambert (2002) concurs with this and asserts that "while statistics inform how systems experience individuals, stories tell us how individuals experience systems". In neonatal care, data is collected to analyse outcomes, admission data and audit practice which can assist service provision planning but there is also a need to 'humanise' care in this field and remember the neonate and family at the heart of care.

Empathy is one such 'emotional message' and a person centred concept that can be applied to neonatal care. As a definition, in relation to the current focus within healthcare, empathy is a cognitive characteristic involving understanding inner experiences and perspectives of individuals (Cooper, 2011) combined with an inherent ability to communicate this back to patients. Understanding what parents go through during their time within a neonatal unit during their neonate's often uncertain journey should not be under-estimated. Research within the medical field in particular has explored the use of stories or narratives to enhance empathic care in various ways (Rosenthal et al, 2011; Shapiro et al, 2006; Tavakol et al (2012). However, again there is less so in nursing especially in specialisms such as neonatal care. There is a need for further research in how narrative and specially storytelling can contribute to enhancing empathy and more specifically into how this can be incorporated into teaching and learning strategies.

Implications for practice. Since the advent of narrative understanding, literature has increasingly articulated how it can be used to construct identity (Squire et al , 2014), 
contribute to sense-making (Missel and Birkelund, 2011; Andrews et al, 2013), serve as a source of implicit communication and facilitate reflection (Moon, 1999; Haidet et al, 2006) and aid education and transformative learning (McDrury and Alterio, 2003; Hoggan and Cranton, 2015). It is the last of these points that this literature review may contribute to; it has highlighted key research findings where narrative is explored and analysed to demonstrate the lived experiences of patients and parents. If one can learn from these narratives to really understand what the patient experiences, then it follows that the health professional would give more empathic, person centred care as distinct from the care that focuses on the clinical skills. What therefore is needed is to incorporate such experiences into teaching and learning strategies and/or resources so that they can be used to educate learners and health professionals about their patients (Fix et al, 2012) and in the case of neonatal about the parents in their care.

Work in other fields has explored how storytelling can impact on professional learning for students in practice. Gidman (2013) for example, explored students' perceptions of patient stories during practice placements which revealed the value of engaging with service users as a resource for learning. It follows that educators should recognise and value this form of teaching to enhance practice based learning. However, providing the space and opportunity for students to listen to stories during their placements and actively facilitate reflection on these learning experiences is an ongoing challenge in the real world of healthcare practice and the question therefore remains on how to address this, particularly challenging in a specialist area such as neonatal care due to the unique nature of the patient and the specific needs they present.

One alternative is to present stories in a digital format rather than in practice itself and literature supports this platform to enhance engagement and reflection (Boase, 2008; Renda, 
2013). Barrett (2006) refers to digital storytelling as a 'deep learning tool' which concurs with the notion of enhancing engagement in learning. A study by Christiansen (2011) explored ways in which digital, patient stories can influence nursing practice and it was concluded that stories act as a useful and powerful learning resource, an emotional or reflective experience and ultimately can promote transformative learning. Similarly, Fenton (2014) recognized the need to include the perspectives of children and young people specifically in the delivery of child focused educational programmes and presented a digital story telling resource based upon a young person's experience of cancer to a group of children's nursing students. Student evaluations of the teaching and learning value found that over $80 \%$ of them rated it as interesting, were motivated to explore its content highlighting that listening to the young person's experiences of treatment assisted the understanding of a patients' perspective of care delivery to gain insight into their lived experiences. Earlier work by Hardy (2007) analysed the value and effectiveness of the Patient Voices website and also concluded that patient digital stories conveyed key emotional messages to health professionals that have the potential for transforming and humanising health care delivery.

However, no such resource is available in the field of neonatal nursing care and so the development of learning resource based on narratives and storytelling could be an alternative and innovative approach to current traditional teaching methods, to enhance understanding of the neonatal care experience.

\section{CONCLUSION}

There is an emerging interest in how stories are used for health professionals to learn how best to care for their patients and understand their experiences. The current higher education environment means that educators cannot remain stagnant in the ways that they teach and innovative methods need to be developed in line with the changing demands on resources and 
curriculum delivery. HEIs that deliver nurse education programmes should work towards developing programmes of blended learning including those that include narrative methods in the form of storytelling, particularly in specialisms such as neonatal care that have specific person-centred needs and that not been explored in this way.

There needs to be a commitment to the development of well-designed learning materials that integrates narrative in the form of storytelling, if this approach to teaching and learning is really to be properly embraced in the nurse education arena. In neonatal care, if assurance is given to developing such materials that capture the neonate's and parent's experience and tell their story, this can be used to support teaching and learning about the vast spectrum of knowledge and skills required to deliver holistic, empathic, person-centred nursing care. 


\section{REFERENCES}

Andrews, M, Squire, C and Tamboukou, M. (2013). Doing Narrative Research (2 $2^{\text {nd }}$ edition). Sage: London

Barrett, H. (2006). Researching and Evaluating Digital Storytelling as a Deep Learning Tool. Retrieved from: http://electronicportfolios.com/portfolios/SITEStorytelling2006.pdf

Boase, C. (2008) Digital storytelling for reflection and engagement, a review of the potential for digital storytelling. Report produced as part of the Phase 1 of The Higher Education Academy / JISC Higher Education e-Learning Pathfinder Programme. Available from http://resources.glos.ac.uk/tli/lets/projects/pathfinder/index.cfm

Brodsky, D., Lamiani, G., Andrade, O., Johnson, V. M., Luff, D., \& Meyer, E. C. (2013). Memorable conversations in neonatal intensive care: A qualitative analysis of interprofessional provider perspectives. Journal of Nursing Education and Practice, 4(3), p38.

Bruner, J. (1991). The Narrative Construction of Reality. Critical Inquiry. 18 (1), 1-21.

Charon, R. (2006) Narrative Medicine: Honouring the Stories of Illness. Oxford University Press: Oxford and New York

Christiansen, A. (2011). Storytelling and professional learning: A phenomenographic study of students' experience of patient digital stories in nurse education. Nurse Education Today, 31(3), 289-293.

Cooper, B. (2011). Empathy in Education. Bloomsbury publishing. London and New York

DasGupta, S. (2007). Between Stillness and Story: Lessons of Children's Illness Narratives. Pediatrics. 119(6), e1384-1391 
Dellenmark-Blom M. \& Wigert, H. (2014) Parents' experiences with neonatal home care following initial care in the neonatal intensive care unit: a phenomenological hermeneutical interview study. Journal of Advanced Nursing, 70(3), 575-586.

Fegran, L and Helseth, S (2009). The parent-nurse relationship in the neonatal intensive care unit context--closeness and emotional involvement. Scand J Caring Sci. 23(4):66773

Fenton, G. (2014). Involving a young person in the development of a digital resource in nurse education. Nurse Education in Practice, 14 (1), 49-54.

Fix, G. M., Houston, T. K., Barker, A. M., Wexler, L., Cook, N., Volkman, J. E., \& Bokhour, B. G. (2012). A novel process for integrating patient stories into patient education interventions: incorporating lessons from theater arts. Patient education and counseling, 88(3), 455-459.

Gidman, J. (2013). Listening to stories: Valuing knowledge from patient experience. Nurse Education in Practice, 13 (3), 192-196.

Green, J., Darbyshire, P., Adams, A., \& Jackson, D. (2015). Looking like a proper baby: Nurses' experiences of caring for extremely premature infants. Journal of Clinical Nursing, 24(1-2), 81-89.

Haidet, P., Kroll, T. L., \& Sharf, B. F. (2006). The complexity of patient participation: lessons learned from patients' illness narratives. Patient Education and Counseling, 62(3), 323-329.

Hardy, P. (2007). An investigation into the application of the Patient Voices Digital Stories in Healthcare Education: quality of learning, policy impact and practice-based value. http://www.pilgrim.myzen.co.uk/papers/phardymsc.pdf

Hardy, P and Haigh, C. (2011). Tell me a Story: A conceptual exploration of storytelling in healthcare education. Nurse Education Today. 31(4),408-11 
Hoggan, C., \& Cranton, P. (2015). Promoting Transformative Learning Through Reading Fiction. Journal of Transformative Education, 13(1), 6-25.

Korhonen, A., \& Kangasniemi, M. (2013). Nurses' narratives on termination of primary nursing relationship with parents in neonatal intensive care. Scandinavian Journal of Caring Sciences. 28, 716-723.

Lambert, J. (2002). Humanising Healthcare in Digital Storytelling: Capturing loves, creating Community. ( $3^{\text {rd }}$ edition). New York: Digital Diner Press.

Lindsay, G., Cross, N., \& Ives-Baine, L. (2012). Narratives of Neonatal Intensive Care Unit Nurses: Experience with End-of-Life Care. Illness, Crisis, \& Loss, 20 (3), 239-253.

Lorem, G.F. (2008). Making sense of stories: the use of patient narratives within mental health care research. Nursing Philosophy, 9, 62-71.

McDrury, M \& Alterio. J. (2003). Learning Through Storytelling in Higher Education: Using Reflection and Experience to Improve Learning. London \& New York: Routledge.

Missel, M., \& Birkelund, R. (2011). Living with incurable oesophageal cancer. A phenomenological hermeneutical interpretation of patient stories. European Journal of Oncology Nursing, 15 (4), 296-301.

Moon J. (1999). Reflection in Learning and professional development. London: Kogan Page,

Polkinghorne, DE. (1988). Narrative Knowing and the Human Sciences. Albany N.Y.: State University of New York Press.

Renda, C. (2013). Evaluating Digital Stories as Multi-Modal Reflections on Experiences. In R. McBride \& M. Searson (Eds.),Proceedings of Society for Information Technology \& Teacher Education International Conference 2013 (pp. 1700-1705). Chesapeake, VA: Association for the Advancement of Computing in Education (AACE). 
Rosenthal, S., Howard, B., Schlussel, Y. R., Herrigel, D., Smolarz, B. G., Gable, B., ... \& Kaufman, M. (2011). Humanism at heart: preserving empathy in third-year medical students. Academic Medicine, 86(3), 350-358.

Russell, G., Sawyer, A., Rabe, H., Bliss, J. A., Gyte, G., Duley, L., \& Ayers, S. (2014). Parents' views on care of their very premature babies in neonatal intensive care units: a qualitative study. BMC Pediatrics, 14(1), 230.

Shapiro, J, Rucker, L, Boker, J and Lie, D. (2006). . "Point-of-view writing: a method for increasing medical students' empathy, identification and expression of emotion, and insight." Education for Health 19(1), 96-105.

Squire, C, Davis, M, Esin, C, Andrews, M, Harrison, B, Hyden, LC and Hyden, M. (2014). What is Narrative Research? London and New York: Bloomsbury Publishing.

Stacey, G amd Hardy, P. (2011). Challenging the shock of reality through digital storytelling. Nurse Education in Practice, 11 (2), 159-64.

Tavakol, S, Dennick, R \& Tavakol, M. (2012). Medical students' understanding of empathy: a phenomenological study. Medical Education, 46, 306-316.

Wigert, H., Johansson, R., Berg, M., \& Hellström, A. L. (2006). Mothers' experiences of having their newborn child in a neonatal intensive care unit. Scandinavian Journal of Caring Sciences, 20 (1), 35-41.

Wigert, H., Blom, M. D., \& Bry, K. (2014). Parents' experiences of communication with neonatal intensive-care unit staff: an interview study. BMC Pediatrics, 14(1), 304.

Wright JM, Heathcote K, Wibberley C (2014) Fact or fiction: exploring the use of real stories in place of vignettes in interviews with informal carers. Nurse Researcher. 21(4), $39-43$. 
Table 1: Search strategy

\begin{tabular}{|c|c|}
\hline A; Sampling strategy & $\begin{array}{l}\text { Purposive sampling: samples from specific disciplines, years } \\
\text { and databases (see B, C \& D below) } \\
\text { Inclusion: Search terms (combined with AND): narrative, } \\
\text { stories (OR) storytelling, nursing, nurse education, neonatal } \\
\text { nursing, neonatal care, educational research, person-centred } \\
\text { care. Electronic search only. } \\
\text { Exclusion: Health education within other disciplines. Hand } \\
\text { searches. }\end{array}$ \\
\hline B; Type of studies & $\begin{array}{l}\text { Inclusion: Research within the nursing discipline using } \\
\text { narrative based, qualitative designs. Studies that focused on } \\
\text { exploration of experience within neonatal care. English } \\
\text { written studies only. Ethical approval obtained. } \\
\text { Exclusion: Research within other fields and healthcare } \\
\text { disciplines; studies using quantitative or survey based } \\
\text { designs. Studies that did not focus on parent or nurse } \\
\text { experiences. Non-English written studies }\end{array}$ \\
\hline C; Range of years & $\begin{array}{l}\text { Inclusion: } 2005 \text { to the end of } 2015 \\
\text { Exclusion: before } 2005\end{array}$ \\
\hline D; Sources & $\begin{array}{l}\text { CINAHL (Cumulative Index of Nursing and Allied Health } \\
\text { Literature) with full text (EBSCO) via NHS Evidence } \\
\text { Healthcare database. The author's HEI's own online search } \\
\text { tool of consolidated databases via library services. }\end{array}$ \\
\hline
\end{tabular}


Table 2: Summary of selected study characteristics for each theme (in chronological order).

\begin{tabular}{|c|c|c|c|c|c|}
\hline Authors & Aim & Methods & Sample & $\begin{array}{l}\text { Findings \& conclusion in relation to } \\
\text { learning about person-centred care }\end{array}$ & Critique / study limitations \\
\hline \multicolumn{6}{|c|}{ Learning from parent narratives } \\
\hline Wigert, 2006 & $\begin{array}{l}\text { To explore } \\
\text { mothers' } \\
\text { experiences of } \\
\text { neonatal care }\end{array}$ & $\begin{array}{l}\text { Phenomenological, } \\
\text { hermeneutic } \\
\text { interview study. } \\
\text { Interviews } 6 \text { month } \\
\text { to } 6 \text { years after } \\
\text { neonatal experience }\end{array}$ & 10 mothers & $\begin{array}{l}\text { Participation or exclusion were found to be a } \\
\text { significant themes in relation to mother's } \\
\text { experience of neonatal care. } \\
\text { The important of diminishing exclusion and } \\
\text { promoting participation by close dialogue } \\
\text { with mothers as unique individuals is needed } \\
\text { to best care for them at a stressful time. }\end{array}$ & $\begin{array}{l}\text { Wide variety of time frame used following post- } \\
\text { neonatal experience. } \\
\text { Mothers of full term neonates only were studied } \\
\text { who were more likely to stay for a shorter time } \\
\text { frame and the sicker, preterm neonates, therefore } \\
\text { a limited application to the neonatal field overall. } \\
\text { Small sample size. Study took place in Sweden } \\
\text { so differences in family care provision needs } \\
\text { consideration when applying to other countries. }\end{array}$ \\
\hline $\begin{array}{l}\text { Fegran and } \\
\text { Helseth, } \\
2009\end{array}$ & $\begin{array}{l}\text { To explore } \\
\text { nurses and } \\
\text { parents } \\
\text { experiences of } \\
\text { the parent- } \\
\text { nurse } \\
\text { relationship in } \\
\text { the care of } \\
\text { preterm } \\
\text { neonates }\end{array}$ & $\begin{array}{l}\text { Ethnographic } \\
\text { design using } \\
\text { participation } \\
\text { observation and in- } \\
\text { depth interviews }\end{array}$ & $\begin{array}{l}6 \text { mothers } \\
6 \text { fathers } \\
6 \text { nurses }\end{array}$ & $\begin{array}{l}\text { Human interaction and communication } \\
\text { including encouragement of participation and } \\
\text { inclusion is vital for a more humanistic } \\
\text { experience for the parents of preterm } \\
\text { neonates }\end{array}$ & $\begin{array}{l}\text { Ethnography enabled the perspectives of } \\
\text { mothers and father as well as nurses. } \\
\text { Preterm neonates are included in this study } \\
\text { which is more reflective of the neonatal unit } \\
\text { population. } \\
\text { Mixed methods are used so more in-depth data } \\
\text { obtained for analysis and application. }\end{array}$ \\
\hline $\begin{array}{l}\text { Dellenmark } \\
\text { and Wigert, } \\
2014\end{array}$ & $\begin{array}{l}\text { To explore } \\
\text { parent's } \\
\text { experience of } \\
\text { neonatal home } \\
\text { care }\end{array}$ & $\begin{array}{l}\text { Phenomenological, } \\
\text { hermeneutic } \\
\text { interview study. }\end{array}$ & $\begin{array}{l}15 \text { mothers } \\
7 \text { fathers }\end{array}$ & $\begin{array}{l}\text { Experience is seen as an emotional and } \\
\text { challenging 'journey'. } \\
\text { Important elements of becoming a parent and } \\
\text { establishing the role as the main caregiver } \\
\text { were identified. Recognition of the desire to } \\
\text { develop this role is required so health } \\
\text { professionals can encourage and nurture this } \\
\text { person-centred connection for parents. }\end{array}$ & $\begin{array}{l}\text { Larger sample size including both parents yields } \\
\text { substantive rich data. } \\
\text { However, the focus on home care rather than } \\
\text { experience within the neonatal unit limits } \\
\text { application. The study took place in Denmark so } \\
\text { applicability to the other settings may be } \\
\text { questioned due to variations in service provision } \\
\text { for home neonatal care between countries. }\end{array}$ \\
\hline
\end{tabular}




\begin{tabular}{|c|c|c|c|c|c|}
\hline $\begin{array}{l}\text { Russell et al, } \\
2014\end{array}$ & $\begin{array}{l}\text { To explore } \\
\text { parent views } \\
\text { on the care } \\
\text { experienced in } \\
\text { the neonatal } \\
\text { unit relating to } \\
\text { their very } \\
\text { preterm } \\
\text { neonate. }\end{array}$ & $\begin{array}{l}\text { Qualitative, } \\
\text { interview based } \\
\text { study }\end{array}$ & $\begin{array}{l}32 \text { mothers } \\
\text { and } 7 \text { fathers }\end{array}$ & $\begin{array}{l}\text { Provision of information, sensitive and } \\
\text { emotional support for parents and increasing } \\
\text { their involvement in the care of their neonate } \\
\text { were all highlighted by parents as important } \\
\text { in their overall experience of care. } \\
\text { Communication with them as individual } \\
\text { people in the humanistic sense was a strong } \\
\text { theme }\end{array}$ & $\begin{array}{l}\text { Sample size large yielding rich data for analysis. } \\
\text { The interviews were conducted between one } \\
\text { month and almost a year after the birth and so } \\
\text { the experience may not have been at the } \\
\text { forefront of the parents' memories for some. }\end{array}$ \\
\hline $\begin{array}{l}\text { Wigert et al, } \\
2014\end{array}$ & $\begin{array}{l}\text { To explore } \\
\text { parents", } \\
\text { experiences of } \\
\text { communicatio } \\
\text { n with staff in } \\
\text { the neonatal } \\
\text { unit. }\end{array}$ & $\begin{array}{l}\text { Hermeneutic, } \\
\text { interview study }\end{array}$ & $\begin{array}{l}27 \text { parents } \\
\text { ( } 16 \text { mothers } \\
\text { and } 11 \\
\text { fathers) }\end{array}$ & $\begin{array}{l}\text { Communication that is attentive is required to } \\
\text { relieve what is called a 'burden 'and parents } \\
\text { viewed communication with the NICU staff } \\
\text { as essential to their management of their } \\
\text { situation. } \\
\text { Nurses are ideally placed to help parents deal } \\
\text { with emotional distress and opportunities } \\
\text { should be sought to enable this and avoid } \\
\text { negative emotional experiences. }\end{array}$ & $\begin{array}{l}\text { A strength lies in relation to the } \\
\text { recommendations for teaching and learning that } \\
\text { were put forward relating to the emotional side } \\
\text { of care. } \\
\text { However, more inclusion of how opportunities } \\
\text { for training of staff can be achieved could have } \\
\text { been put forward. As above, study took place in } \\
\text { Sweden where resource provision of family } \\
\text { centred care may vary. }\end{array}$ \\
\hline \multicolumn{6}{|c|}{ Learning from nurses' narratives } \\
\hline $\begin{array}{l}\text { Lindsay et al, } \\
2012\end{array}$ & $\begin{array}{l}\text { To explore } \\
\text { experiences of } \\
\text { neonatal } \\
\text { nurses with } \\
\text { end-of-life } \\
\text { care }\end{array}$ & $\begin{array}{l}\text { Interpretative, } \\
\text { narrative approach } \\
\text { using group story } \\
\text { writing and phone } \\
\text { conversations }\end{array}$ & $\begin{array}{l}17 \text { neonatal } \\
\text { nurses }\end{array}$ & $\begin{array}{l}\text { Analysis of stories revealed the importance } \\
\text { of nurses forming relationships with parents } \\
\text { in this very sensitive and difficult situation. } \\
\text { In such a challenging area, person-centred } \\
\text { relationships are essential. } \\
\text { Three patterns were evidence in the dialogue- } \\
\text { Call to presence, knowing / not knowing and } \\
\text { exploring experience for transformation of } \\
\text { practice }\end{array}$ & $\begin{array}{l}\text { Presents a novel approach to narrative inquiry by } \\
\text { the use of story writing and analysis using phone } \\
\text { conversations of said stories. Stories may offer } \\
\text { more honest and open accounts of experience } \\
\text { compared to interviews. } \\
\text { A very focused and specialised area is examined } \\
\text { rather than neonatal care experience as a whole. } \\
\text { More suggestions are required for addressing the } \\
\text { emotional demands of nurses when dealing with } \\
\text { this situation. }\end{array}$ \\
\hline
\end{tabular}




\begin{tabular}{|c|c|c|c|c|c|}
\hline $\begin{array}{l}\text { Brodsky et } \\
\text { al, } 2013\end{array}$ & $\begin{array}{l}\text { To explore } \\
\text { health } \\
\text { professionals } \\
\text { experience } \\
\text { and } \\
\text { perspective of } \\
\text { difficult } \\
\text { conversations } \\
\text { in neonatal } \\
\text { care. }\end{array}$ & $\begin{array}{l}\text { Interpretive } \\
\text { narrative analysis } \\
\text { using an } \\
\text { educational } \\
\text { programme } \\
\text { including reflecting } \\
\text { on end of life care } \\
\text { followed by } \\
\text { participant free } \\
\text { writing about their } \\
\text { experiences of } \\
\text { difficult } \\
\text { conversations. }\end{array}$ & $\begin{array}{l}74 \text { health } \\
\text { professionals } \\
\text { (nurses, } \\
\text { physicians, } \\
\text { psychosocial } \\
\text { professionals } \\
\text { and } \\
\text { respiratory } \\
\text { therapists) }\end{array}$ & $\begin{array}{l}\text { Difficult conversations included those on } \\
\text { uncertain outcomes, unexpected diagnoses, } \\
\text { clinical deterioration and dealing with } \\
\text { emotional responses of parents. } \\
\text { Describing and writing about memorable } \\
\text { neonatal conversations from the provider } \\
\text { perspective, can encourage health } \\
\text { professionals to reflect upon and continually } \\
\text { refine their approach to communicating with } \\
\text { families. } \\
\text { There is a real need for educational strategies } \\
\text { to assist health professionals deal with this } \\
\text { challenging area. }\end{array}$ & $\begin{array}{l}\text { A multi-professional approach is offered and a } \\
\text { large study examining a range of different } \\
\text { narrative perspectives. } \\
\text { Key proposals are proposed for practice } \\
\text { development around teaching and learning- for } \\
\text { example, relationship focused educational } \\
\text { strategies to facilitate person-centred care. } \\
\text { The differing views between professionals was } \\
\text { not examined and written narratives only were } \\
\text { used. Further clarification of points, which could } \\
\text { have been achieved by individual interviews. }\end{array}$ \\
\hline $\begin{array}{l}\text { Korhonen } \\
\text { and } \\
\text { Kangasniemi, } \\
2014\end{array}$ & $\begin{array}{l}\text { To describe } \\
\text { nurses' } \\
\text { experiences of } \\
\text { ending the } \\
\text { primary } \\
\text { relationship } \\
\text { with parents in } \\
\text { the neonatal } \\
\text { intensive care } \\
\text { unit (NICU) }\end{array}$ & $\begin{array}{l}\text { Qualitative, } \\
\text { narrative design } \\
\text { using in-depth } \\
\text { interviews and } \\
\text { narrative analysis }\end{array}$ & $\begin{array}{l}7 \text { neonatal } \\
\text { nurses }\end{array}$ & $\begin{array}{l}\text { A caring relationship between nurses and } \\
\text { parents is essential in neonatal nursing: this } \\
\text { relationship is described as a plot from the } \\
\text { point of forming the relationship and through } \\
\text { the process of caring for the neonate to when } \\
\text { this relationship ends. } \\
\text { The relationship between nurses and parents } \\
\text { is seen as a vital humanistic element of the } \\
\text { care environment and ending the above } \\
\text { relationship can be challenging and an } \\
\text { emotional experience. }\end{array}$ & $\begin{array}{l}\text { Takes a novel approach to how the nurse-parent } \\
\text { relationship is conceptualised in relation to a plot } \\
\text { through a process from start to finish. } \\
\text { A small scale study which describes the } \\
\text { relationship, particularly how it ends, rather than } \\
\text { analyses it per se } \\
\text { More links could be made between the meaning } \\
\text { of the relationship ending to future practice- i.e. } \\
\text { what is required to facilitate this difficult } \\
\text { process. }\end{array}$ \\
\hline $\begin{array}{l}\text { Green et al, } \\
2015\end{array}$ & $\begin{array}{l}\text { To explore } \\
\text { how neonatal } \\
\text { nurses draw } \\
\text { meaning from } \\
\text { their } \\
\text { experiences }\end{array}$ & $\begin{array}{l}\text { Interpretive, } \\
\text { phenomenological } \\
\text { approach using } \\
\text { semi-structured } \\
\text { interviews }\end{array}$ & $\begin{array}{l}14 \text { neonatal } \\
\text { nurses }\end{array}$ & $\begin{array}{l}\text { Many challenges were revealed for nurses in } \\
\text { the care of extremely preterm neonates, such } \\
\text { as their 'foetal' appearance. } \\
\text { Nurse employed strategies such as } \\
\text { depersonalisation and detachment to help }\end{array}$ & $\begin{array}{l}\text { This research explored the experiences and } \\
\text { difficulties of caring for human neonates who } \\
\text { resemble foetuses rather than infants allowing an } \\
\text { honest and unique perspective not studied } \\
\text { previously. }\end{array}$ \\
\hline
\end{tabular}




\begin{tabular}{|l|l|l|l|l|}
\hline $\begin{array}{l}\text { with } \\
\text { extremely } \\
\text { preterm } \\
\text { neonates }\end{array}$ & & $\begin{array}{l}\text { deal with caring for these neonates and also } \\
\text { that minimised the foetal appearance. }\end{array}$ & $\begin{array}{l}\text { Relevance to clinical practice is very brief and } \\
\text { no recommendations are offered to enable a } \\
\text { supportive working environment that recognises } \\
\text { such challenges. }\end{array}$ \\
$\begin{array}{l}\text { It is important to understand the nature of } \\
\text { stress facing this specialised are of nursing } \\
\text { and supportive work environments could } \\
\text { help to reduce stress and facilitate better care } \\
\text { of very small neonates. }\end{array}$ & \\
\hline
\end{tabular}

